University of Warwick institutional repository: http://go.warwick.ac.uk/wrap This paper is made available online in accordance with publisher policies. Please scroll down to view the document itself. Please refer to the repository record for this item and our policy information available from the repository home page for further information.

To see the final version of this paper please visit the publisher's website. Access to the published version may require a subscription.

Author(s): Eleanor Nesbitt

Article Title: Studying the Religious Socialization of Sikh and 'Mixed-

Faith' Youth in Britain: Contexts and Issues

Year of publication: 2009

Link to published version: http://dx.doi.org/10.1163/187489208X382901

Publisher statement: None 


\title{
Research Report:
}

\section{Studying the Religious Socialization of Sikh and 'Mixed-Faith' Youth in Britain: Contexts and Issues ${ }^{1}$}

\author{
Eleanor Nesbitt \\ Institute of Education, University of Warwick \\ Coventry CV4 7AL, UK \\ eleanor.nesbitt@warwick.ac.uk
}

\begin{abstract}
Against a backdrop of phases of Sikh settlement in the UK, this article provides an overview of scholarship on UK Sikh communities. Attention turns to four ethnographic studies conducted by the author, two of which focused on unambiguously Sikh communities, and two of which challenge presuppositions of the boundedness of faith communities. Of these one was a study of two historically stigmatised caste-specific Punjabi communities; the other is currently examining the religious identity formation of young people in families in which only one parent is Sikh. Pointers and questions are identified that arise from these UK studies for researchers in mainland Europe. These include methodological considerations and encouragement to contribute to debates in the sociology of religion and to take account of Sikhs’ increasing appearance in creative literature.
\end{abstract}

\footnotetext{
${ }^{1}$ The text is based on a paper delivered at the Exploratory Workshop on the Sikhs in Europe: History, Religion and Representation, University of Lund, 14 June 2008.
} 


\section{Keywords}

Sikh, socialisation, caste, mixed-faith, boundaries, Great Britain, Europe, religion

\section{Introduction}

Studies of UK Sikhs are part of the wider field of Sikh studies in the UK, a field which includes study of Punjabi language, Sikh history and scriptural texts. Before India's independence from British rule in 1947 British administrators and others had classified Punjabi communities and recorded Sikhs’ history. But it was Gurdip Singh Aurora’s publication in $1967^{2}$ which ushered in a new period of UK Sikh studies which would be dominated by reports of fieldwork among British Sikhs and would be authored not only by gore (Punjabi for 'white people'), but also by Sikhs themselves.

Since the early 1950s, Sikhs of the Jat zat (i.e. caste), mainly from the Jalandhar doaba region of Punjab (i.e. the area between the rivers Satluj and Beas), had been settling in considerable numbers in Britain's industrial cities. Before this there had been a few princely or royalty-connected visitors to Britain in the late nineteenth and early twentieth centuries, and between the two world wars a substantial number of Sikh men of the Bhatra caste had settled, principally in Britain’s seaports. By 1967 some Ramgarhia Sikhs also lived in the UK and around 1970 the number of Ramgarhias climbed steeply as Sikh families were displaced by the Africanisation policies in countries such as Uganda,

\footnotetext{
${ }^{2}$ Gurdip S. Aurora, The New Frontiersmen: A Sociological Study of Indian Immigrants in the UK (Bombay: Popular Prakashan, 1967).
} 
Kenya and Tanzania and arrived as 'twice migrants. ${ }^{3}$ Here it may be helpful to explain that the majority of Sikhs, both worldwide and in the UK, are from the Jat caste, whose members are by tradition peasant farmers, proud of owning land, however fragmented their holdings may have become. By contrast, the Bhatras and Ramgarhias are 'landless'. Bhatra men in India were often itinerant, surviving by, for example, telling fortunes. Ramgarhias were skilled craftsmen-brick-layers, masons, blacksmiths, and carpenters. Whereas the Bhatras and almost all the Jats migrated to the UK directly from India, Ramgarhias came chiefly from the countries of east Africa, where many Ramgarhia families had been resident for the better part of the twentieth century. More detail of these phases of migration and settlement can be found in publications by Roger Ballard, ${ }^{4}$ Eleanor Nesbitt, ${ }^{5}$ and by Gurharpal Singh and Darshan Singh Tatla. ${ }^{6}$ In the 1990s Afghan Sikhs arrived, mainly in Southall in Greater London, as a fifth phase of Sikh migration. ${ }^{7}$

Sikhs are now a substantial and well-established minority in the UK, numbering 336,000 according to the 2001 census. This was the first UK census since the mid-

\footnotetext{
${ }^{3}$ Parminder Bhachu, Twice Migrants: East African Sikh Settlers in Britain (London: Tavistock, 1985).

${ }^{4}$ Roger Ballard, "Differentiation and Disjunction among the Sikhs in Britain,” in: N. Gerald Barrier \& Verne A. Dusenbery (eds.) The Sikh Diaspora: Migration and the Experience beyond Punjab (Columbia Ma: South Asia Books, 1989), 200-234; Roger Ballard, "The Growth and Changing Character of the Sikh Presence in Britain,” in: Harold G. Coward, Raymond Brady Williams \& John R. Hinnells (eds.), The South Asian Religious Diaspora in Britain, Canada, and the United States (New York: State University of New York Press, 2000), 127-144.

${ }^{5}$ Eleanor Nesbitt, Sikhism: A Very Short Introduction (Oxford: Oxford University Press, 2005), 90-91.

${ }^{6}$ Gurharpal Singh \& Darshan Singh Tatla, Sikhism in Britain: The Making of a Community (London: Zed, 2006).

${ }^{7}$ Caroline Moorhead “Inderjeed [sic] Singh: Lost in Kabul,” Open Democracy, http://www.opendemocracy.net/people/article_1373.jsp (accessed 21 May 2008).
} 
nineteenth century to include a 'religious question', and the figure was lower than most contemporary estimates had been. The census return disclosed Sikhs to be outnumbered not only by Christians and Muslims but also (contrary to some previous estimates, both by scholars and by Sikhs) by Hindus (numbering about 560,000).

In this article I shall recommend that Sikh studies in Europe engage with not only social anthropological studies of British Sikhs, and indeed with wider theorisation of diaspora, but also with the sociology of religion. This engagement is indeed crucial in the case of studies of my own specialism which is religious socialisation i.e. the intergenerational transmission of Sikh faith, values and culture. For, as the French sociologist, Danièle Hervieu-Léger, demonstrates:

Transmission to younger generations is the very process by which religion constitutes itself as a religion across time. Thus, the question of transmission is at the centre of a sociology of religious modernity. ${ }^{8}$

At the same time, our attention as researchers to works of scholarship in the social sciences must not divert us from, on the one hand, the study of history and Gurmukhi religious writings, and, on the other hand, Sikhs’ increasing visibility in creative literature, drama, and film.

Studies, subsequent to Aurora's, which provide context for my own research include substantial research by Parminder Bhachu, ${ }^{9}$ Arthur Helweg in Gravesend, ${ }^{10}$ and by

8 Danièle Hervieu-Léger, “The Role of Religion in Establishing Social Cohesion,” Eurozine. http://www.eurozine.com/articles/2006-08-17-hervieuleger-en.html (accessed 27 March 2008), 213.

${ }^{9}$ Bhachu, Twice Migrants.

${ }^{10}$ Arthur Helweg, Sikhs in England: The Development of a Migrant Community (New Delhi: Oxford University Press, 1979); Arthur Helweg, Sikhs in England (New Delhi: Oxford University Press, 1986). 
Roger Ballard, ${ }^{11}$ joined more recently by Gurharpal Singh and Darshan Tatla’s overview of Sikhs in Britain. ${ }^{12}$ Smaller, locally-focused publications include those by Kitty Fitzgerald, featuring Manchester Sikhs, ${ }^{13}$ Ramindar Singh on Bradford Sikhs, ${ }^{14}$ and sociology turned into fiction-Hannah Bradby on Glasgow Punjabis. ${ }^{15}$ In parallel with the emphasis on locality, themes and issues have been explored, including the Indian Workers' Association, ${ }^{16}$ turban controversies, ${ }^{17}$ the phenomenon of sants (spiritual leaders), ${ }^{18}$ Sikhs as a transnational diaspora ${ }^{19}$ that is mobilising politically, ${ }^{20}$ Sikh women, ${ }^{21}$

\footnotetext{
${ }^{11}$ Ballard, “Differentiation” and “Growth.”

${ }^{12}$ Singh \& Singh Tatla, Sikhism.

${ }^{13}$ Kitty Fitzgerald, Speaking for Ourselves: Sikh Oral History (Manchester: Manchester Sikh History Pro-
} ject, 1986).

${ }^{14}$ Ramindar Singh, Immigrants to Citizens: The Sikh Community in Bradford (Bradford: The Race Relations Research Unit, 1992).

${ }^{15}$ Hannah Bradby, Skinfull (London: Womenonly Press, 2005).

${ }^{16}$ De Witt John, Indian Workers Associations in Britain (London: Oxford University Press for Institute of Race Relations, 1969).

${ }^{17}$ David Beetham, Transport and Turbans: A Comparative Study in Local Politics (Oxford: Oxford University Press for Institute of Race Relations, 1970).

${ }^{18}$ Joy Barrow, "Religious Authority and Influence in the Diaspora: Sant Jaswant Singh and Sikhs in West London,” in: Pashaura Singh \& N. Gerald Barrier (eds.), Sikh Identity: Continuity and Change (New Delhi: Manohar, 2001), 335-348. Eleanor Nesbitt, “The Nanaksar Movement,” Religion 15 (1985), 67-79. Darshan Singh Tatla, "Nurturing the Faithful: The Role of the Sant among Britain’s Sikhs,” Religion 22/4 (1992), 349-374.

${ }^{19}$ Darshan Singh Tatla, The Sikh Diaspora: The Search for Statehood (London: UCL Press, 1999).

${ }^{20}$ Giorgio Shani, Sikh Nationalism and Identity in a Global Age (London: Routledge, 2008). 
hereditary and denominational groupings i.e. respectively, zat and sampradaya, ${ }^{22}$ the bhangra music scene, ${ }^{23}$ and Sikhs in football. ${ }^{24}$

Of particular relevance to my own focus on the socialisation of young Sikhs is the pioneering, Huddersfield-based study by Alan James. ${ }^{25}$ Relevant too are studies by the educationist J. S. Dosanjh and the psychologist Paul Ghuman, ${ }^{26}$ as well as Kathleen Hall's school-based examination of Sikh youth as British citizens. ${ }^{27}$ Santokh Singh Gill's

${ }^{21}$ Satwant K. Rait, Sikh Women in England: Religious, Social and Cultural Beliefs (Stoke on Trent: Trentham, 2005).

${ }^{22}$ Sewa Singh Kalsi, The Evolution of a Sikh Community in Britain (Leeds: Community Religions Project, University of Leeds, 1992); Opinderjit Takhar, Sikh Identity: An Exploration of Groups among Sikhs (Aldershot: Ashgate, 2005). A sampradaya can, loosely, be defined as a guru-led movement. In the Sikh case it is contentious both to suggest that Sikhs constitute a sampradaya within the wider Indic/Hindu society and to draw attention to separate sampradayas within Sikh society.

${ }^{23}$ Rajinder Dudrah, Bhangra: Birmingham and Beyond (Birmingham: Birmingham City Council and Punch Records, 2007).

${ }^{24}$ Jas Bains \& Sanjiev Johal, Corner Flags and Corner Shops: The Asian Football Experience (London: Phoenix, 1998).

${ }^{25}$ Alan G. James, Sikh Children in Britain (London: Oxford University Press for Institute of Race Relations, 1974).

${ }^{26}$ This includes J. S. Dosanjh, “A Comparative Study of Punjabi and English Child-rearing Practices with Special Reference to Lower Juniors (7-9 years)," unpublished PhD thesis: University of Nottingham, 1976; and J. S. Dosanjh \& Paul A. S Ghuman, Child-Rearing in Ethnic Minorities (Clevedon: Multilingual Matters, 1996).

${ }^{27}$ Kathleen D. Hall, Lives in Translation: Sikh Youths as British Citizens (Philadelphia: University of Pennsylvania Press, 2002). 
doctoral work on young male Sikhs and masculinity is a further contribution to understandings of young UK Sikhs. ${ }^{28}$

\section{My Sikh-Related Research Projects}

My own empirically based studies of Sikh socialisation form part of a range of research on cultural transmission, adaptation, and religious nurture that has also included my work on young British Hindus and ethnically diverse Christians. ${ }^{29}$ For these studies religious education has been the professional framework as my immediate context has, since 1984, been (what has been called for the greater part of this time) the Warwick Religions and Education Research Unit. Much of the Unit's work has centred on the interpretive approach, articulated by the Unit's director, Robert Jackson, who has in turn drawn on the work of Cantwell Smith, Clifford Geertz and many others. ${ }^{30}$ My ethnographic studies provided an empirical underpinning to Jackson's discussion of faith traditions in terms of 'membership groups.' While Jackson advocated enabling students to 'build bridges’ between their own experience and concepts and those which they encounter when studying

\footnotetext{
${ }^{28}$ Santokh S. Gill, "Being Sikh: Constructions of Masculinity and Identity amongst Young British Sikh Men,” unpublished PhD thesis: University of Derby, 2005.

${ }^{29}$ Robert Jackson \& Eleanor Nesbitt, Hindu Children in Britain (Stoke on Trent: Trentham, 1993); Eleanor Nesbitt, Intercultural Education: Ethnographic and Religious Approaches (Brighton: Sussex Academic Press, 2004); Eleanor Nesbitt, “Invisible Minority: South Asian Christians in the UK,” in: Knut Jacobsen \& Selva Raj (eds.), South Asian Christian Diaspora (Aldershot: Ashgate, 2008).

${ }^{30}$ Robert Jackson, Religious Education: An Interpretive Approach (London: Hodder \& Stoughton, 1997).
} 
faith communities, my work has explored the 'gap’ between young people’s lived experience of their religious tradition and the curricular representation of their tradition in schools. I argue that for education to be constructive, intercultural teachers need to be sensitised (through conducting or reading ethnographic studies, for example) to the 'close-up' reality of members of faith communities in the UK. ${ }^{31}$ One of my continuing objectives has been informing policy and practice in relation to this statutory (and multifaith) subject of the basic school curriculum, as well as contributing to intercultural education and the multi-disciplinary field of religious studies.

\subsection{Two Studies of Unambiguously Sikh Communities}

For my unambiguously Sikh-focused projects—all of them ethnographic—I have researched religious and cultural transmission in Sikh families in Nottingham 1979-1980 32 and — with funding from the Economic and Social Research Council—the religious nurture of 8-13 year old Sikhs in Coventry in $1991 .^{33}$ The methods consisted of participant observation (mainly in gurdwaras) and semi-structured interviewing in schools and family homes.

To begin with the Nottingham-based study, key findings in 1979-1980 concerned the importance of zat (i.e. whether communities were of Jat, Bhatra, and Ramgarhia

\footnotetext{
${ }^{31}$ Nesbitt, Intercultural Education.

32 Eleanor Nesbitt, “Aspects of Sikh Tradition in Nottingham” (unpublished MPhil thesis: University of Nottingham, 1980).

${ }^{33}$ Eleanor Nesbitt, The Religious Lives of Sikh Children: A Coventry Based Study (Leeds: Community Religions Project, University of Leeds, 2000) and Eleanor Nesbitt, Intercultural Education.
} 
caste, on which see above) in differentiating families' experience. My data showed that, with regard to education, while the young Bhatra women were expected to leave school at 16, if not earlier, and to marry soon after that, their Jat and Ramgarhia peers were encouraged to do well at school and to go on to higher education. As far as employment was concerned, the Bhatra women were allowed to earn money only by work within the home — in a shop that was a part of the same premises, for example-whereas the Jat and Ramgarhia women were expected to have paid employment and in most cases this was away from home.

In the Coventry study, focusing as it did on eight to fourteen year old Sikhs from Ramgarhia and Jat families, the subject of zat (caste) emerged again. Many of the Jat respondents attended the Ramgarhia gurdwara (even although non-Ramgarhias are not eligible for membership of the committees of Ramgarhia gurdwaras), and (as in the case of the Jat and Ramgarhia families in Nottingham) no zat-related difference in educational aspiration or anticipated age for marriage was evident. As I was subsequently to discover, zat was also playing a significant part in Coventry in relation to two other hereditary communities of Punjabi background (see below). For the young Coventrian Sikhs, selfidentification was a central focus, and this involved perceptions of caste- their own and other Sikhs' - together with the prevalent equation of 'Sikh' with 'Punjabi,' plus a tendency to distinguish between 'Sikhs' and 'proper Sikhs' on the basis of factors that included appearance (the Sikh look), involvement in the gurdwara, and zat. ${ }^{34}$

The Coventry study explored processes of informal nurture (conditioning within home and family) and formal nurture: classes (in Punjabi language and devotional music)

\footnotetext{
${ }^{34}$ Nesbitt, Religious Lives, 217-241.
} 
and Sikh camps. In relation to religious education in UK schools, discrepancies between the lived reality of Sikhs and 'textbook' representations emerged strongly, in particular regarding usage and understandings of the English word 'God,' as well as attitudes and experience with regard to both caste and gender. ${ }^{35}$ My data revealed the extent to which Sikhs' understanding and usage of the word amrit illustrated another discrepancy between the young Sikhs' beliefs and practices and the 'Sikhism' of the curriculum books, as, when these young Sikhs and their families referred to amrit what they most often had in mind was empowering, transforming water that had, most usually, been stored close to the Guru Granth Sahib during an akhand path ("continuous reading”) and then brought home. ${ }^{36}$ In the textbooks, however, amrit referred only to the sweetened water that is central to the rite of initiation into the Khalsa.

\subsection{Two Sikh-Related studies}

Two of my other research projects, while not having a focus that was so unambiguously Sikh, are most certainly relevant to the study of Sikhs in mainland Europe. Both these studies focused on socialisation and identity formation and both studies challenge the neat demarcations of 'world faiths' in religious education in primary and secondary schools and (quite often) in the study of religion on university level.

\footnotetext{
${ }^{35}$ Nesbitt, Religious Lives and eadem, Intercultural Education.

${ }^{36}$ Nesbitt, Religious Lives, 182-214; eadem, Intercultural Education, 66-81. For a superb discussion of the popular applications of amrit (based, however, not in the UK but on Sikhs in Banaras, India) see Kristina Myrvold, Inside the Guru's Gate: Ritual Uses of Texts among the Sikhs in Varanasi (Lund: Department of History and Anthropology of Religions, Lund University, 2007), 275-285.
} 
In the first project that ran from 1988 to 1989-with funding from the Leverhulme Trust-I examined religious nurture in two low-caste Punjabi communities, the Valmikis and Ravidasis. ${ }^{37}$ In both communities individuals’ religious identification and marriages and the communities' styles of public and private worship span the supposed boundary between 'Hinduism' and 'Sikhism.' This research also uncovered the castebased prejudice to which Valmikis and Ravidasis are subjected in the UK by, in most instances, Jat Sikhs and the structural and social separateness of two historically oppressed communities despite their shared experience of discrimination.

At this point it is worth noting that caste discrimination implicating Sikhs is increasingly featuring in literature authored by UK Punjabis. Movingly, a recent play by two women from castes affected by discrimination ${ }^{38}$ and the autobiographies of two Jats, Jasvinder Sanghera ${ }^{39}$ and Sathnam Sanghera, ${ }^{40}$ highlight the hurtful divide between Jat Sikhs and Punjabis of the lowest castes. In April 2008 a national newspaper featured a poem by a Jat poet, Daljit Nagra, a rap which evoked in a 'Punglish' (i.e .a type of Eng-

\footnotetext{
${ }^{37}$ Eleanor Nesbitt, “‘My Dad’s Hindu, My Mum’s Side are Sikhs’: Issues in Religious Identity,” 1993, available online at http://www.art.man.ac.uk/CASAS/papers/pdfpapers/identity.pdf (accessed 8 August 2008).

${ }^{38}$ Rena D. Annobil \& Reena Bhatoa, The Fifth Cup, unpublished play, premiered in Birmingham's Drum Theatre in 2007. See http://www.casteawayarts.com/whatson/thefifthcup (accessed 21 May 2008).

${ }^{39}$ Jasvinder Sanghera, Shame (London: Hodder, 2006).

${ }^{40}$ Sathnam Sanghera, If You Don't Know Me by Now: A Memoir of Love, Secrets and Lies in Wolverhampton (London: Viking, 2008), 313-314.
} 
lish mixed with Punjabi words), probably mystifyingly for most readers, the taboo on sexual relations between the Valmiki and Ravidasi communities. ${ }^{41}$

Clearly my study of socialisation in Coventry's Valmiki and Ravidasi communities, like this flurry of recent creative writing, has implications for the representation of 'world religions' in religious education, and more radically for a widely accepted religious studies framework which assumes that 'religions' are discrete, and that caste is a structural principle of Hindu society that 'Sikhism' has rejected. In unsettling the 'world religions’ paradigm the Coventry study has contributed to literature which challenges accepted boundaries $^{42}$ and which contests essentialised representations of religions, ${ }^{43}$ and so it has provided support for contemporary rethinking of the emergence of 'religions' and 'world faiths' continuous with historical re-examination of nineteenth and twentieth century South Asia. ${ }^{44}$ All this is relevant to researchers embarking on research among Sikhs elsewhere in Europe.

The second project, too, has for its focus another (increasing) social phenomenon which defies the tidy compartmentalising of 'religions' and 'faith communities.' From

${ }^{41}$ Daljit Nagra, “Jhoota Kunda Ballads The Ghosts of Cranford Park,” Review, The Guardian (The Saturday Poem), 26 April 2008, 22.

${ }^{42}$ Ron Geaves, "The Borders between Religions: A Challenge to the World Religions Approach to Religious Education,” British Journal of Religious Education 21/1 (1998), 20-31; Jacqueline Suthren Hirst, Mary Searle-Chatterjee \& Eleanor Nesbitt, "Report on Teaching South Asian Religious Traditions,” The PRS-LTSN Journal 1/1 (2001), 77-79.

${ }^{43}$ Robert Jackson, Religious Education: An Interpretive Approach (London: Hodder and Stoughton, 1997).

${ }^{44}$ Harjot Oberoi, The Construction of Religious Boundaries: Culture, Identity and Diversity (Delhi: Oxford University Press, 1994); W. Hew McLeod, Who Is a Sikh? The Problem of Sikh Identity (Oxford: Clarendon, 1989). 
2006 to 2009 the empirical research (which is currently being carried out under my direction by my colleague, Elisabeth Arweck, with funding from the Arts and Humanities Research Council), is examining the religious identity formation of young people in mixedfaith families. These families include eight families in which one parent is from a Sikh family and one parent is from either a Hindu or a Christian background. In this study, too, the methods have been ethnographic, although it has proved impossible to conduct observation other than during home visits for the purpose of interview. The intention of more innovatively incorporating elements of cyberethnography (primarily using the internet for the purpose of locating a sample and for interviewing by e-mail) also foundered, and so the research has relied mainly on semi-structured interviews in the home or by telephone, including the small element of observation that was possible (indeed unavoidable) during those visits. $^{45}$

The 2006-2009 research into the religious identity formation of young people in mixed-faith families challenges and contextualises studies that extract 'a Sikh community’ from our variously plural global and European society. By ‘variously plural’ I invoke the analysis by Geir Skeie ${ }^{46}$ and Robert Jackson ${ }^{47}$ of 'traditional' and 'modern' plurality. For whereas 'traditional plurality' refers to societies comprising diverse religious

\footnotetext{
${ }^{45}$ Elisabeth Arweck \& Eleanor Nesbitt, "Methodological Issues in the Investigation of the Religious Identity Formation of Young People in Mixed-Faith Families,” submitted to International Journal of Qualitative Studies in Education.

${ }^{46}$ Geir Skeie, "Plurality and Pluralism: A Challenge for Religious Education,” British Journal of Religious Education 17/2 (1995), 84-91.

${ }^{47}$ Robert Jackson, Rethinking Religious Education and Plurality: Issues in Diversity and Pedagogy (London: RoutledgeFalmer, 2004).
} 
and ethnic groups, as a result of successive migrations, in 'modern plurality' (or 'postmodern' plurality) individuals have multiple intersecting identities and are influenced in numerous overlapping ways. As Hall explains, in relation to 'second generation Sikhs,' Sikh tradition has been 'disembedded' from Punjab, ${ }^{48}$ and she sums up their agency in constructing their identities thus: "[I]dentities are produced in relation to multiple forms of discourse that circulate into people's lives through various channels and in relation to distinctive forms of cultural or identity politics." ${ }^{\text {49 }}$ This modern plurality can be experienced as spiritual plurality, a drawing (conscious or otherwise) by individuals on many streams of religious and philosophical tradition. ${ }^{50}$ The speed and variety of communication, intrinsic to globalisation, is matched by structural change inherent in the increased incidence of inter-community marriages and partnerships.

Although data from the investigation of religious identity-formation in mixedfaith families have not yet been fully analysed, some early observations may be relevant in thinking forward to future European projects. The data consist more of parents sharing their story than of young people articulating their experience. It seems likely that most of the parents were 'secular,' or at least somewhat distanced from being observant members of the religious communities with which, however, they admit an at least nominal identification. The Sikh parents, for example, visit the gurdwara occasionally for langar (the communal vegetarian meal that has been, since the time of the first Gurus, a central institution in Sikh life, exemplifying social equality as well as provision for the hungry) and

\footnotetext{
${ }^{48}$ Hall, Lives, 9.

${ }^{49}$ Ibid., 14.

${ }^{50}$ Eleanor Nesbitt, Interfaith Pilgrims (London: Quaker Books, 2003), 22-23.
} 
for weddings, but for nothing more. In one case a Sikh parent was distanced from her community prior to marriage, and in one case the Sikh partner had been rejected by her parents because of marrying out and has subsequently experienced a resurgence of community identification. One observation regarding the continuing of religious practice concerns the family's location: the nearness of family members and of a gurdwara. Grandparents feature in most families' narratives, but in a variable role-for example, as a necessary factor in their grandchildren's learning Punjabi, or as treating their half-English grandchildren differently from their fully Punjabi grandchildren. In one case Grandma lives opposite; but as her granddaughter and she have no common language, the granddaughter voiced a sense of closeness mixed with frustration.

Apparent is a tendency by the Sikh parents (as indeed among their Hindu and Christian spouses) to accept secular UK cultural norms without difficulty. In one family the mother (from a Sikh family) voluntarily participated in a more actively Christian milieu as she attended the parish church (for both a spiritual and a pragmatic reason) whereas her husband (from a Christian family) did not. At the same time, unfamiliarity with Punjabi or English is in some extended families a barrier between members. Moreover, Sikh social norms, such as gender segregation at social functions, had damaged one marital relationship.

The young people accept having parents from different religious backgrounds and —in the case of the Christian-Sikh families—from visibly different ethnic communities as being how things are, rather than as being unusual or problematic. The researchers found a strong sense of a double inclusion in one family (where both parents were from the same Punjabi caste and the mother was an observant Mormon), and a sense of double 
marginalisation in another family. In this case the child, who had, as mentioned above, lamented being unable to communicate with her grandmother, also expressed regret. She was sad, simultaneously, both because she had turned down (she assumed, irrevocably) the chance to attend Punjabi classes and because she had not been christened). In the Sikh-Mormon family the principle of seva (service) was identified by the Mormon mother as a shared value. Moreover, she found that Mormon teaching on the importance of family reinforced, and was reinforced by, Punjabi/Sikh emphases.

\section{Issues Arising for Future Researchers}

From my experience during these four pieces of research some issues for future investigations in Europe arise, regarding both procedure and focus. What is more, amid the multitude of disciplinary approaches that are invoked I would urge researchers to engage with insights from the sociology of religion.

\subsection{A Sociology of Religion Framework}

Whatever their geographical setting, Sikhs (as people who are defined primarily by religion rather than by ethnicity) need to be contextualised in the wider sociology of religion: for example, Hervieu-Léger suggests that there are societies of memory which change into societies of change, and that religion is a chain of memory. ${ }^{51}$ She pays attention to

\footnotetext{
${ }^{51}$ Danièle Hervieu-Léger, Religion as a Chain of Memory (Cambridge: Polity Press, 2000).
} 
the commonality of Europe's religious heritage, as Christian (in the sense of Catholic and Protestant, but not Orthodox) and to the national divergences (exemplified by the German Reformation, the French Revolution, etc.) which continue to play themselves out. In Hervieu-Léger's analysis authority has given way to autonomies and the dissolving of 'law' (even the laws of nature); what is more, insecurities (e.g. regarding war and food) have been replaced by new insecurities (jobs etc.).

The work of Hervieu-Léger’s fellow sociologist of religion, Grace Davie, suggests the usefulness of applying to our study of Sikh communities her theoretical distinction between 'believing without belonging' and 'belonging without believing. ${ }^{52}$ In this regard, my observations among UK communities suggest that the most pertinent axes may not so much be 'believing' and 'belonging' as 'identity' and 'participation.' Robert Wuthnow's distinction between 'dwellers' and 'seekers' ${ }^{53}$ and Hervieu-Léger’s of 'pilgrims’ and ‘converts’ offer two other typologies. Certainly writers on processes of identity formation in Europe will need language that allows for the "dynamic, changeable and more fluid realities.”54

The applicability of Hervieu-Léger’s disaggregation of 'socialisation' to, for example, the part-Sikh families of my current empirical study, indicates the relevance of her analysis for future research. The dimensions of socialisation that she proposes are: communal (e.g. membership of a congregation), ethical (following rules and espousing val-

\footnotetext{
${ }^{52}$ Grace Davie, Religion in Britain since 1945 (Oxford: Blackwell, 1994).

${ }^{53}$ Cited from J. Carroll \& W. C. Roof, Bridging Divided Worlds: Generational Changes in Congregations (San Francisco: Jossey-Bass, 2002), 39; see Douglas Davies \& Matthew Guest, Bishops, Wives and Children: Spiritual Capital Across the Generations (Aldershot: Ashgate, 2007), 129.

${ }^{54}$ Davies \& Guest, Bishops, 129.
} 
ues), emotional (identity, or missing some aspect), cultural (including language, weddings), 'political' and 'aesthetic' (e.g. pilgrimage) ${ }^{55}$ Her discussion of individuals asserting their 'right to bricolage' also merits examination in a wide context of competing influences, and careful consideration of the level of agency and knowledge that individuals actually have. ${ }^{56}$

Another typology worthy of consideration comes from Roberta Ricucci, writing on young people of Moroccan and Filipino families in Italy. ${ }^{57}$ Her categories are: 'tightrope walkers' (who attend a place of worship for cultural reasons); 'indifferent' individuals (who do not go to a place of worship or speak a heritage language); 'marginal' individuals (who do not speak the language of the host society); and those who are 'involved' (displaying a high level of attachment to their community's values and engagement in both the society and in religious associations). The study of religious socialisation in Sikh and part-Sikh families in the UK and Europe more widely needs to be informed by the discourse of sociologists of religion and has its own contribution to offer to understanding of fragmentation and of memory.

\subsection{Methodology and Method}

\footnotetext{
${ }^{55}$ Danièle Hervieu-Léger, "The Transmission and Formation of Socioreligious Identities in Modernity: An Analytical Essay on the Trajectories of Identification,” International Sociology 13, 2 (1998), 213-228.

${ }^{56}$ Hervieu-Léger, “Transmission,” 217.

${ }^{57}$ Roberta Ricucci, “Religion and the Adolescent Immigrants: A Way of Identifying with or Turning from their Communities?,” paper presented to the biannual conference of the International Society for the Sociology of Religion, Leipzig, July 2007.
} 
My own studies suggest that the methodological questions which need to be followed up include whether future investigations would be better served by a combination of quantitative survey with the ‘thick description' to which ethnographers aspire. Another question is: What will be the place, scope, and contribution of cyberethnography? Barbara Wintersgill $^{58}$ has recently demonstrated the potential of interview through email in her exploration of teenagers' understandings of 'spirituality' whereas the experience of Elisabeth Arweck and myself has been of families’ strong preference for face-to-face/personal encounter.

Those planning future studies need to balance a spatial conceptualisation of enquiries as cartographic (mapping a research terrain) or topographic (focusing more narrowly) with a temporal conceptualisation of synchronic or diachronic research. ${ }^{59}$ Clearly, longitudinal study is called for if trends are to be charted.

As research becomes more consciously reflexive, a researcher's positionality (the next issue to be considered) spans both methodology and focus, as the interaction between researchers and the field is intrinsic to both. On this issue, while Bhopal ${ }^{60}$ and others argue for commonality between the researcher and the researched, the researcher who is an insider (by gender, ethnicity, religion, etc.) to the community concerned must exer-

\footnotetext{
${ }^{58}$ Barbara Wintersgill, “Teenagers' Perceptions of Spirituality,” unpublished PhD thesis, University of Warwick, 2008.

${ }^{59}$ Anastasia Karaflogka, E-Religion: A Critical Appraisal of Religious Discourse on the World Wide Web (London: Equinox, 2006).

${ }^{60}$ Kalwant Bhopal, “Gender, 'Race’ and Power in the Research Process: South Asian Women in East London,” in: Carole Truman, Donna M. Mertens \& Beth Humphries (eds.), Research and Inequality (London: UCL Press), 67-79.
} 
cise vigilance regarding potential 'observer blindness' and her/his hitherto unexamined assumptions. In designing the study and interpreting the data, one's position on the insider/outsider spectrum requires ongoing scrutiny and a recognition that differently positioned researchers will produce research that is different but (if they are reflexively alert) not 'better' or 'worse. ${ }^{61}$ The merits of reflexive teamwork, involving both relative 'insider' and relative 'outsider' (a Sikh and a non-Sikh, for example) deserve serious attention, as well as teamwork between researchers of different levels of experience. ${ }^{62}$

\subsection{Focus for Enquiries}

The focus of investigations is likely to continue to be on dynamics and processes, and these could include migration histories (the push and pull factors for once, twice, and thrice migrants) of Sikhs in European countries, and the examination of conditions in the host society. ${ }^{63}$ It also remains to be seen what part, if any, individuals' zat plays in their experience of settlement. Certainly the studies in Nottingham and Coventry suggest the value of exploration of social structures and the dynamics of zat in relation to these and to identity formation. Are there parallels in other European contexts to the different trajecto-

\footnotetext{
${ }^{61}$ Damian Breen, "Reflections on the Positionality of the White, Male, Non-Muslim Researcher in Muslim Primary Schools: The Realities of Researching Muslim Women,” in: Working Papers, Series IV (Coventry: Institute of Education, University of Warwick), (forthcoming 2008).

62 Janet Siltanen, Alette Willis \& Willow Scobie, “Separately Together: Working Reflexively as a Team,” International Journal of Social Research Methodology 11/1 (2008), 45-61.

${ }^{63}$ Kim Knott, "Bound to Change? The Religions of South Asians in Britain” in: Steven Vertovec (ed.), Aspects of the South Asian Diaspora (New Delhi: Oxford University Press, 1991), 86-111.
} 
ries of Bhatra, Jat, and Ramgarhia in the UK and the persistence of experience of zatlinked oppression or discrimination? As far as continuing the exploration of marrying out and mixed-faith families, studies of part-Sikh families can augment a literature which currently includes Karen Leonard's study of Mexican Sikh families in the USA ${ }^{64}$ and-in Europe-Muslim-Christian families in Germany. ${ }^{65}$

My research, in line with the quotation from sociologist of religion, Danièle Hervieu-Léger, suggests the potential contribution to be made by exploring and theorising religious socialisation — the role of parents, of the gurdwara, supplementary classes, families’ visits to India, etc., as well as the role of the internet, of other media, and of family members, especially grandparents. ${ }^{66}$ Future studies may reveal the experience of young people in partly Sikh families as compared with the experience of young people both of whose parents are Sikhs. This experience may include the degree of identification as European, Sikh, Punjabi, etc., as well as levels of integration, racism, and so on. I await applications in new contexts of such concepts (well-worn in UK scholarship) as situ-

\footnotetext{
${ }^{64}$ Karen I. Leonard, Making Ethnic Choices: California's Punjabi Mexican Americans (Philadelphia: Temple University Press, 1992).

${ }^{65}$ Regine Froese, “One Family, Two Religions: Child belief or Child Grief in Christian-Muslim Families?,” British Journal of Religious Education 30/1 (2008), 37-47.

${ }^{66}$ Our research contributes to the literature cited in Keith Littler, "Who Says Grandparents Matter?,” Journal of Beliefs and Values 29/1 (2008), 51-60, whose own research suggests the link between the religiosity of grandparents and that of their grandchildren in a Welsh Anglican context.
} 
ational identity, multiple cultural competence, ${ }^{67}$ and integrated plural identity, a concept outlined by Sissel Østberg on the basis of her study of young Pakistanis in Oslo. ${ }^{68}$

Co-ordinated studies of Sikh communities in a range of European countries may be informed by studies of the longer established, more numerous Sikh population in the UK, and also by studies of other communities in the same national context (as, for example, awareness of Jewish history can inform research on subsequent immigration to the UK). National specificities will include religious and colonial history, legislation, and economic circumstances, such as in Italy the need by producers of Parmesan cheese for dairy workers ${ }^{69}$ and the possibility for legally entering Italy to work in the circus. ${ }^{70}$ Some commonalities may include the effect of 9/11 on local attitudes to recent Sikh migrants, or the effect of events in Punjab on the radicalisation or politicisation of some diaspora Sikhs, or revival/reinvention of 'tradition' such as bhangra. The latter two suggestions arise from recent UK media coverage—in particular two items, one on television and the

\footnotetext{
${ }^{67}$ Jackson \& Nesbitt, Hindu Children.

${ }^{68}$ Sissel Østberg, Pakistani Children in Norway: Islamic Nurture in a Secular Context (Leeds: Community Religions Project, University of Leeds, 2003).

${ }^{69}$ See Francesca Galloni’s research cited in Francesca Gobbi, "Ethnographic research as a Re/Source of Intercultural Education," Austrian Studies in Anthropology 1 (2005); available online at http://www.univie.ac.at/alumni.ethnologie/journal/vol1txt/InterculturalEducation.pdf (accessed 31 May 2008).

${ }^{70}$ See Barbara Bertolani, “The Sikhs in Italy: The Role of Ethnic and Family Networks in Immigration and Social Integration Processes,” paper presented at Exploratory Workshop on the Sikhs in Europe: History, Religion and Representation, University of Lund, June 2008.
} 
other on radio. ${ }^{71}$ The continental research will in turn provide new ideas and contexts for Sikh studies researchers in the UK.

\section{Concluding Comment}

Commitment to keeping abreast of current scholarship should not exclude attention to much earlier diagnoses and prognoses. In post 9/11 Europe Alan James’ tentative forecast, based on his research nearly 40 years ago, merits revisiting:

One could even see Sikh youth 'outdoing' their parents in religious fanaticism: they might initiate a movement [...] to revive or 'purify' the Sikh religion. Wearing of turbans could become an act of defiance not just against the hostile white community but against the more nervous or half-hearted Sikhs. ${ }^{72}$

Finally, researchers in Europe are commended to look at as wide a range of literature as possible. Biography, autobiography, novels, short stories and poetry offer valuable insights and can generate hypotheses and provide rich contexts of lived experience. Reading about the violent Hardjit [sic!] and his gang in a recent novel entitled Londonstani ${ }^{73}$ might, for example, lead into areas such as crime, whereas reading Sanghera’s autobiog-

\footnotetext{
${ }^{71}$ Channel 4, "Immigration: The Inconvenient Truth,” 14 April 2008; and Radio 4, "Sikh Terror: The UK Connection,” File on Four, 26 February 2008.

${ }^{72}$ James, Sikh Children, 102-103.

${ }^{73}$ Gautam Malkani, Londonstani (London: Harper Collins, 2006).
} 
raphy would contribute to shaping a proposal to look into Sikh (and other minority groups) and mental illness. ${ }^{74}$

And how long will it be before creative writing and film produced by and about Sikhs in mainland Europe becomes a focus for study? Already Kip (Kirpal Singh), the hero of Canadian Sri Lankan novelist Michael Ondaatje’s The English Patient, has introduced readers and audiences internationally to a fictional Sikh sapper in post World War II Italy, ${ }^{75}$ although—as Nikky Singh argues ${ }^{76}$ — the film has failed Sikhs. Not so Bend It Like Beckham, the 2002 hit produced by British Sikh screen writer Gurinder Chadha, centring on an aspiring footballer, a young woman from an East African UK Sikh family. UK screenplay writer Gurpreet Kaur's controversial drama Behzti ${ }^{77}$ set in a West Midlands gurdwara, has been translated into French by Rudi Bekaert, 'staged-read in Brussels,' produced in Belgium and France and published by the French theatre publisher, Les Solitaires Intempestifs. ${ }^{78}$

The contemporary arts and creative writing scene complements my ethnographic research in suggesting potential subjects, issues, and methodological considerations for those embarking on studying Sikhs in Europe. At the same time, it is to be hoped that-in the interests of Sikh Studies as a whole-scholars in European countries, including the

\footnotetext{
${ }^{74}$ Sanghera, If You Don't Know Me by Now.

${ }^{75}$ Michael Ondaatje, The English Patient (New York: Knopf Publishing House, 1993).

${ }^{76}$ Nikky Singh, “Twice Repressed: The Case of Ondaatje’s Kip,” Journal of Religion and Film 8/1, 2004; available online at http://www.unomaha.edu/jrf/Vol8No1/EnglishPatient.htm (accessed 21 May 2008).

${ }^{77}$ See Singh \& Tatla, Sikhism.

${ }^{78}$ See http://en.wikipedia.org/wiki/Behzti (accessed 1 July 2008).
} 
UK, will balance the burgeoning study of contemporary phenomena with rigorous research into scripture and history from earlier centuries.

\section{References}

Annobil, Rena.D. \& Reena Bhatoa, The Fifth Cup, unpublished play, premiered 2007; available online at http://www.casteawayarts.com/whatson/thefifthcup (accessed 21 May 2008).

Arweck, Elisabeth \& Eleanor. Nesbitt, "Methodological Issues in the Investigation of the Religious Identity Formation of Young People in Mixed-Faith Families,” submitted to International Journal of Qualitative Studies in Education.

Aurora, Gurdip S., The New Frontiersmen: A Sociological Study of Indian Immigrants in the UK (Bombay: Popular Prakashan, 1967).

Bains, Jas \& Sanjiev Johal, Corner Flags and Corner Shops: The Asian Football Experience (London: Phoenix, 1998).

Ballard, Roger, "Differentiation and Disjunction among the Sikhs in Britain," in: N. G. Barrier \& Verne A. Dusenbery (eds.), The Sikh Diaspora: Migration and the Experience beyond Punjab (Columbia MA: South Asia Books, 1989), 200-234.

Ballard, Roger, “The Growth and Changing Character of the Sikh Presence in Britain” in: Harold G. Coward, Raymond Brady Williams \& John R. Hinnells (eds.), The South Asian Religious Diaspora in Britain, Canada, and the United States (New York: State University of New York Press, 2000), 127-144. 
Barrow, Joy, "Religious Authority and Influence in the Diaspora: Sant Jaswant Singh and Sikhs in West London” in: Pashaura Singh \& N. Gerald Barrier (eds.) Sikh Identity : Continuity and Change (New Delhi: Manohar, 2001), 335-348.

Beetham, David, Transport and Turbans: A Comparative Study in Local Politics (Oxford: Oxford University Press for Institute of Race Relations, 1970).

Bertolani, Barbara, “The Sikhs in Italy: The Role of Ethnic and Family Networks in Immigration and Social Integration Processes,” unpublished paper presented at the Exploratory Workshop on The Sikhs in Europe: History, Religion and Representation, University of Lund, 13 June 2008.

Bhachu, Parminder, Twice Migrants: East African Sikh Settlers in Britain (London: Tavistock, 1985).

Bhopal, Kalwant, “Gender, 'Race' and Power in the Research Process: South Asian Women in East London,” in: C. Truman, D. M. Mertens \& B. Humphries (eds.), Research and Inequality (London: UCL Press, 2000), 67-79.

Bradby, Hannah, Skinfull (London: Onlywomen Press, 2005).

Breen, Damian, "Reflections on the Positionality of the White, Male, Non-Muslim Researcher in Muslim Primary Schools: The Realities of Researching Muslim Women,” in: Working Papers, Series IV (Coventry: Institute of Education, University of Warwick, forthcoming2008).

Carroll, Jackson W. \& Wade C. Roof, Bridging Divided Worlds: Generational Changes in Congregations (San Francisco: Jossey-Bass, 2002).

Channel 4, “Immigration: The Inconvenient Truth,” 14 April 2008.

Davie, Grace, Religion in Britain since 1945 (Oxford: Blackwell, 1994). 
Davies, Douglas \& Matthew Guest, Bishops, Wives and Children: Spiritual Capital across the Generations (Aldershot: Ashgate, 2007).

Dosanjh, J. S., “A Comparative Study of Punjabi and English Child-Rearing Practices with Special Reference to Lower Juniors (7-9 Years),” unpublished PhD thesis, University of Nottingham, 1976.

Dosanjh, J. S. \& Paul A. S. Ghuman, Child-Rearing in Ethnic Minorities (Clevedon: Multilingual Matters, 1996).

Dudrah, Rajinder, Bhangra: Birmingham and Beyond (Birmingham: Punch records, 2007).

Fitzgerald, Kitty, Speaking for Ourselves: Sikh Oral History (Manchester: Manchester Sikh History Project, 1986).

Froese, Regine, “One Family, Two Religions: Child Belief or Child Grief in ChristianMuslim Families?” British Journal of Religious Education 30/1 (2008), 37-47.

Geaves, Ron, “The Borders between Religions: A Challenge to the World Religions Approach to Religious Education,” British Journal of Religious Education 21/1 (1998), 20-31.

Gill, Santokh S., "Being Sikh: Constructions of Masculinity and Identity amongst Young British Sikh Men,” unpublished PhD thesis, University of Derby, 2005.

Gobbi, Francesca, "Ethnographic Research as a Re/Source of Intercultural Education,” Austrian Studies in Anthropology, Sondernummer 1 (2005), 6-17; available online

at http://www.univie.ac.at/alumni.ethnologie/journal/vol1txt/InterculturalEducation. pdf (accessed 31 May 2008). 
Hall. Kathleen D., Lives in Translation: Sikh Youths as British Citizens (Philadelphia: University of Pennsylvania Press, 2002).

Helweg, Arthur W., Sikhs in England: The Development of a Migrant Community (New Delhi: Oxford University Press, 1979).

Helweg, Arthur, Sikhs in England (New Delhi: Oxford University Press, 1986).

Hervieu-Léger, Danièle, “The Transmission and Formation of Socioreligious Identities in Modernity: An Analytical Essay on the Trajectories of Identification,” International Sociology 13, 2 (1998), 213-228.

_ $\quad$ Religion as a Chain of Memory (Cambridge: Polity Press, 2000).

— “The Role of Religion in Establishing Social Cohesion,” Eurozine (2006); available online at http://www.eurozine.com/articles/2006-08-17-hervieuleger-en.html (accessed 27 March 2008).

Jackson, Robert, Religious Education: An Interpretive Approach (London: Hodder and Stoughton, 1997).

— $\quad$ Rethinking Religious Education and Plurality: Issues in Diversity and Pedagogy (London: Routledge Falmer, 2004).

Jackson, Robert \& Eleanor Nesbitt, Hindu Children in Britain (Stoke on Trent: Trentham, 1993).

James, Alan G., Sikh Children in Britain (London: Oxford University Press for Institute of Race Relations, 1974).

John, De Witt, Indian Workers Associations in Britain (London: Oxford University Press for Institute of Race Relations, 1969). 
Kalsi, Sewa S., The Evolution of a Sikh Community in Britain (Leeds: Community Religions Project, University of Leeds, 1992).

Karaflogka, Anastasia, E-Religion: A Critical Appraisal of Religious Discourse on the World Wide Web (London: Equinox, 2006).

Knott, Kim, "Bound to Change? The Religions of South Asians in Britain,” in: Steven Vertovec (ed.), Aspects of the South Asian Diaspora (New Delhi: Oxford University Press, 1991), 86-111.

Leonard, Karen I., Making Ethnic Choices: California's Punjabi Mexican Americans (Philadephia: Temple University Press, 1992).

Littler, Keith, “Who Says Grandparents Matter?,” Journal of Beliefs and Values 29/1 (2008), 51-60.

McLeod, W.Hew, Who is a Sikh? The Problem of Sikh Identity (Oxford: Clarendon, 1989).

Malkani, Gautam, Londonstani (London: Harper Collins, 2006).

Moorhead, Caroline, “Inderjeed Singh: Lost in Kabul,” Open democracy 2003; available online at http://www.opendemocracy.net/people/article_1373.jsp (accessed 21 May 2008).

Myrvold, Kristina, Inside the Guru's Gate: Ritual Uses of Texts among the Sikhs in Varanasi (Lund: Department of History and Anthropology of Religions, Lund University, 2007).

Nagra, Daljit, “Jhoota Kunda Ballads The Ghosts of Cranford Park,” Review, The Guardian (The Saturday Poem), 26 April 2008, 22. 
Nesbitt, Eleanor, “Aspects of Sikh Tradition in Nottingham,” unpublished M Phil thesis, University of Nottingham, 1980.

— “The Nanaksar Movement,” Religion 15 (1985), 67-79.

— “ “My Dad's Hindu, My Mum’s Side are Sikhs”: Issues in Religious Identity,” 1993, available online at http://www.art.man.ac.uk/CASAS/papers/pdfpapers/identity.pdf (accessed 1 July 2008).

- $\quad$ The Religious Lives of Sikh Children: A Coventry Based Study (Leeds: Community Religions Project, University of Leeds, 2000).

- Interfaith Pilgrims: Living Truths and Truthful Living (London: Quaker Books, 2003).

- Intercultural Education: Ethnographic and Religious Approaches (Brighton: Sussex Academic Press, 2004).

- $\quad$ Sikhism A Very Short Introduction (Oxford: Oxford University Press, 2005).

- “Invisible Minority: South Asian Christians in the UK,” in: K. Jacobsen \& S. Raj (eds.), South Asian Christian Diaspora (Aldershot: Ashgate, 2008).

Oberoi, Harjot, The Construction of Religious Boundaries: Culture, Identity and Diversity (Delhi: Oxford University Press, 1984).

Ondaatje, Michael, The English Patient (New York: Knopf Publishing House, 1993).

Østberg, Sissel, Pakistani Children in Norway: Islamic Nurture in a Secular Context (Leeds: Community Religions Project, Department of Theology and Religious Studies, University of Leeds, 2003).

Radio 4, “Sikh Terror: The UK Connection,” File on Four, 26 February 2008. 
Rait, Satwant K., Sikh Women in England: Religious, Social and Cultural Beliefs (Stoke on Trent: Trentham, 2005).

Ricucci, Roberta, "Religion and the Adolescent Immigrants: A Way of Identifying with or Turning from their Communities?” paper presented to the biannual conference of the International Society for the Sociology of Religion, Leipzig, July 2007.

Sanghera, Jasvinder, Shame (London: Hodder, 2006).

Sanghera, Sathnam, If You Don't Know Me by Now: A Memoir of Love, Secrets and Lies in Wolverhampton (London: Viking, 2008).

Shani, Giorgio, Sikh Nationalism and Identity in a Global Age (London: Routledge, 2008).

Siltanen, Janet, Alette Willis \& Willow Scobie, “Separately Together: Working Reflexively as a Team,” International Journal of Social Research Methodology 11/1 (2008), 45-61.

Singh, Gurharpal. \& Darshan S. Tatla, Sikhism in Britain: The Making of a Community (London: Zed, 2006).

Singh, Nikky, “Twice Repressed: The Case of Ondaatje’s Kip,” Journal of Religion and Film 8/1 (2004); available online at http://www.unomaha.edu/jrf/Vol8No1/EnglishPatient.htm (accessed 21 May 08).

Singh, Ramindar, Immigrants to Citizens: The Sikh Community in Bradford (Bradford: The Race Relations Research Unit, 1992).

Skeie, Geir, "Plurality and Pluralism: A Challenge for Religious Education,” British Journal of Religious Education, 17/2 (1995), 84-91. 
Suthren Hirst, Jacqueline, Mary Searle-Chatterjee \& Eleanor Nesbitt, "Report on Teaching South Asian Religious Traditions,” Centre for Applied South Asian Studies, The PRS-LTSN Journal 1/1 (2001), 77-79.

Takhar, Opinderjit, Sikh Identity: An Exploration of Groups among Sikhs (Aldershot: Ashgate, 2005).

Tatla, Darshan S., "Nurturing the Faithful: The Role of the Sant among Britain’s Sikhs,” Religion 22/4 (1992), 349-374.

Tatla, Darshan S., The Sikh Diaspora: The Search for Statehood (London: UCL Press, 1999).

Wintersgill, Barbara, “Teenagers’ Perceptions of Spirituality,” unpublished PhD thesis, University of Warwick, 2008. 